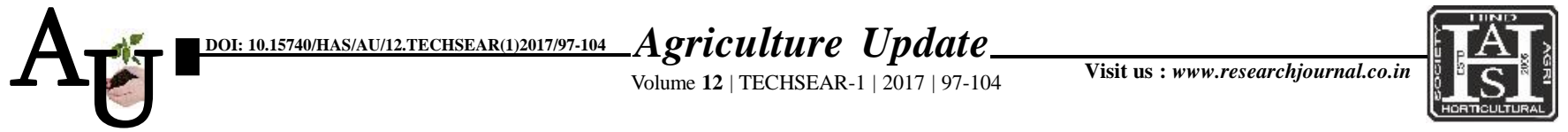

e ISSN-0976-6847

\title{
Research Article: Efficacy of Pseudomonas fluorescens against the pink bollworm, Pectinophora gossypiella (Saunders) (Lepidoptera: Gelechiidae)
}

\author{
T.R. MANJULA, G.S. KANNAN AND P. SIVASUBRAMANIAN
}

Article Chronicle :

Received :

05.07.2017;

Accepted :

22.07.2017

KEY Words:

Pectinophora

gossypiella,

Pseudomonas

flourescens, Bt cotton
SUMMARY : An investigation was carried out during 2014-15 and 2015-16 to evaluate the Pseudomonas fluorescens against the pink bollworm, Pectinophora gossypiella (Saunders), in Bt cotton at Vanavarayar Institute of Agriculture, Pollachi. Apart from the infestation, comparative cseed cotton yield was also assessed. The obtained results indicated that all treatments except control exhibited great reduction in pink bollworm infestation of both green boll damage and locule boll damage percentage and the larval population. The treatment could be arranged descendingly according to the general reduction of two seasons follows; Triazophos $0.05 \%$, Soil and Foliar application of P. fluorescens @ 1\%, Foliar application of P. fluorescens @1\% and Beauveria basianna@1\%, Foliar application of Beauveria basianna @ $1 \%$, Foliar application of P. fluorescens @ 1\% and Soil application of P. fluorescens $2.5 \mathrm{~kg} / \mathrm{ha}$ against pink bollworm.

How to cite this article : Manjula, T.R., Kannan, G.S. and Sivasubramanian, P. (2017). Efficacy of Pseudomonas fluorescens against the pink bollworm, Pectinophora gossypiella (Saunders) (Lepidoptera: Gelechiidae). Agric. Update, 12(TECHSEAR-1) : 97-104; DOI: 10.15740/HAS/AU/12.TECHSEAR(1)2017/97-104.

\section{Author for correspondence :}

\section{T.R. MANJULA}

Department of

Entomology,

Vanavarayar Institute of Agriculture,

Manakkadavu,

POLLACHI (T.N.) INDIA

Email:manjulatr@gmail.

com

See end of the article for

authors' affiliations 